\title{
Pengaruh Penggunaan Alat Peraga terhadap Hasil Pembelajaran Matematika pada Anak Usia Dini
}

\author{
Suwardi, Masni Erika Firmiana, Rohayati \\ Program Studi PG. PAUD, Fakultas Pendidikan dan Psikologi \\ Universitas Al Azhar Indonesia, Jl.Sisingamangaraja, Jakarta 12110 \\ Penulis untuk korespondensi/E-mail: suwardi@uai.ac.id
}

\begin{abstract}
Abstrak - Perbaikan kualitas pendidikan yang salah satunya diindikasikan dengan peningkatan hasil pembelajaran, tidak lepas dari usaha perbaikan dalam pembelajaran. Hasil pembelajaran dipengaruhi beberapa faktor diantaranya penggunaan alat peraga oleh pendidik dalam proses belajar mengajar. Penggunaan alat peraga dalam proses pembelajaran pada sekolah dasar (SD) sangat membantu meningkatkan pemahaman konsep dan keterampilan terhadap materi pelajaran yang diajarkan terutama pelajaran matematika. Rumusan masalah dalam penelitian ini apakah ada pengaruh penggunaan alat peraga terhadap hasil pemelajaran matematika. Penelitian ini bertujuan untuk mengetahui pengaruh pengunaan alat peraga dengan tanpa alat peraga dalam kegiatan belajar mengajar khususnya mata pelajaran matematika dengan memperhatikan hasil belajar anak didik pada usia dini. Penelitian ini menggunakan dua kelompok, yaitu kelompok eksperimen dan kelompok kontrol . Subjek penelitian yang dilibatkan dalam penelitian ini berjumlah 25 siswa pada kelompok eksperimen dan 25 siswa kelas pada kelompok kontrol, maka jumlah keseluruhan yang diteliti sebanyak 50 siswa. Komparasi penelitian dilakukan pada kelompok eksperimen dengan menggunakan alat peraga, sedangkan pada kelompok kontrol tanpa menggunakan alat peraga. Teknik yang digunakan dalam pengumpulan data yang digunakan tes akhir berbentuk isian. Metode penelitian yang digunakan adalah deskriptif kuantitatif dengan ANAVA. Berdasarkan analisis hasil penelitian diperoleh dengan nilai $F_{\text {hitung }}=62,443$ dan signifikansi $>\alpha=0,05$ sehingga dapat disimpulkan terdapat pengaruh signifikan penggunaan alat peraga terhadap hasil belajar matematika pada anak usia dini,
\end{abstract}

Kata Kunci - Alat peraga, hasil belajar, anak usia dini

\section{PENDAHULUAN}

\section{Latar Belakang Masalah}

$\mathrm{P}$ endidikan pada dasarnya adalah suatu proses membantu manusia dalam mengembangkan dirinya sehingga mampu menghadapi segala perubahan dan permasalahan dengan sikap terbuka dan kreatif tanpa kehilangan identitas dirinya, seperti yang tercantum dalam tujuan Pendidikan Nasional yang dirumuskan sebagai berikut: Pendidikan Nasional bertujuan mencerdaskan kehidupan bangsa dan mengembangkan manusia Indonesia seutuhnya, yaitu manusia yang beriman dan bertaqwa terhadap Tuhan Yang Maha Esa dan berbudi pekerti luhur, memiliki pengetahuan dan keterampilan, kesehatan jasmani dan rohani, kepribadian yang mantap dan mandiri serta rasa tanggungjawab kemasyarakatan dan kebangsaan.
Dengan demikian setiap bagian dari proses belajar mengajar yang dirancang dan diselenggarakan harus mempunyai sumbangan nyata untuk mencapai tujuan Pendidikan Nasional. Salah satunya pada proses pembelajaran matematika.Sejalan dengan itu mata pelajaran matematika tidak hanya sekedar diperoleh berbagai pengetahuan dan keterampilan, tetapi mendorong siswa untuk mengembangkan pemahaman dan penghayatan terhadap prinsip, nilai dan proses, dan menumbuhkan daya nalar, berpikir logis, sistematis, kritis, kreatif, cerdas. rasa keindahan, terbuka dan rasa ingin tahu sesuai dengan filsafat matematika.

Sejalan dengan pikiran tersebut, maka guru matematika hendaknya menguasai kumpulan pengetahuan, menguasai proses, pendekatan dan metode matematika yang sesuai sehingga 
mendukung siswa berpikir kritik, menggunakan nalar secara efektif, serta menanamkan benih sikap ilmiah dan disiplin, bertanggung jawab, keteladanan, dan rasa percaya diri disertai dengan iman dan taqwa. Dengan bekal tersebut diharapkan siswa memiliki kemampuan menghadapi masa datang yang selalu berubah, dan menjadi manusia yang berkualitas yang diperlukan untuk pembangunan bangsa.

Untuk keberhasilan tersebut dalam proses pembelajaran diperlukan media atau alat peraga yang dapat mempertinggi proses dan hasil belajar yang berkenaan dengan taraf berpikir siswa. Piaget membagi perkembangan kognitif kedalam empat fase, yaitu fase sensorimotor untuk anak usia 0-2 tahun, fase praoperasional untuk anak usia 2-7 tahun, fase operasi konkret untuk anak usia 7-11 tahun, dan fase operasi formal untuk anak usia 12 tahun keatas [4].

Sesuai dengan perkembangan yang dikemukakan oleh Piaget, usia 7 sampai 12 tahun termasuk dalam fase operasi konkret, dimana kemampuan anak untuk berpikir logis sudah berkembang dengan syarat objek yang menjadi sumber berpikir logis tersebut hadir secara konkret, maka dalam pengajaran matematika hendaknya di usahakan penggunaan alat peraga dimana yang abstrak dapat dikonkretkan. Sesuai tingkat perkembangannya maka siswa dalam pembelajaran matematika diperlukan alat peraga yang tepat.Kenyataannya masih ada sekolah yang tidak menggunakan alat peraga yang tidak tepat, sehingga berpengaruh terhadap hasil belajar siswa [4].

Dengan berbagai permasalahan yang ada, maka peneliti mengambil kesimpulan bahwa diperlukan perwujudan dalam meningkatkan kemampuan dan potensi yang dimiliki anak didik, sehingga diperlukan penelitian komparasi penggunaan alat peraga matematika pada anak usia dini.

\section{B. Perumusan Masalah}

Berdasarkan latar belakang yang telah diuraikan di atas, maka rumusan masalahnya adalah :

1. Bagaimana hasil belajar matematika siswa yang menggunakan alat peraga?

2. Apakah terdapat perbedaan hasil belajar siswa yang menggunakan alat peraga dengan tanpa alat peraga?
3. Apakah siswa yang belajar matematika dengan menggunakan alat peraga lebih baik daripada tanpa menggunakan alat peraga?

\section{Tujuan dan Urgensi Penelitian}

Tujuan Khusus dan urgensi penelitian ini adalah untuk, memberikan sumbangan terhadap perkembangan keilmuan, khususnya untuk bidang ilmu pendidikan, terutama mengenai pentingnya menggunakan alat peraga terutama matematika dalam proses belajar mengajar agar dapat dicapai hasil yang maksimal dan masukan bagi guru untuk mengembangkan penggunaan alat peraga secara optimal, sehingga menjadikan keluaran anak didik yang lebih baik serta menambah pengetahuan dan wawasan tentang perbedaan hasil belajar siswa yang menggunakan alat peraga.

\section{STUDI PUSTAKA}

\section{Anak Usia Dini dan Perkembangannya}

John Amos Comenius, seorang ahli ilmu jiwa anak mengemukakan bahwa anak bukanlah miniatur orang dewasa, tetapi merupakan makhluk kecil yang diyakini memiliki potensi untuk berkembang[10]. Lubis menyatakan bahwa anak harus dipahami bukan sebagai embrio orang dewasa melainkan dalam sosok alami anak agar orang dewasa dapat memahami kemampuan mereka dan mengetahui bagaimana cara berhubungan dengan mereka[10].

Usia 6-8 tahun merupakan awal usia sekolah yang sebenarnya bagi anak. Masa ini merupakan masa peralihan dari masa pra sekolah ke masa sekolah. Pada usia ini anak dikatakan berada pada masa peralihan dari masa kanak-kanak awal ke masa kanak-kanak akhir yaitu usia 8 tahun ke atas. Sesuai dengan pembagian tahap perkembangan individu menurut Piaget, maka pada masa ini anak berada dalam masa peralihan dari tahap praoperasional ke tahap operasional konkret [10].

Pada tahap pra-operasional pada usia 2-7 tahun, anak secara berangsur-angsur dapat memikirkan lebih dari satu benda pada saat yang bersamaan. Mereka mulai menguasai lambang-lambang yang memungkinkan manipulasi secara mental.Akan tetapi penalaran masih sangat dipengaruhi oleh persepsi.Pemakaian bahasa masih egosentris, katakata yang di ucapkan mempunyai makna yang khas. Karena itu kemampuan mereka untuk memandang pendapat orang lain masih terbatas [10]. 
Pada tahap operasi konkret pada usia 7-12 tahun, anak-anak telah mampu memikirkan lebih dari satu benda pada saat bersamaan dan dapat memahami bahwa benda yang berbeda bentuknya mempunyai volume yang sama. Akan tetapi pemikirannya masih terbatas mengenai benda yang kongkrit dan akan kesulitan apabila menggeneralisasikan lebih dari itu [10].

\section{Matematika dan Hakikatnya}

Menurut pendapat Jonson dan Rising tentang matematika yaitu [6]:

1. Matematika adalah pola berpikir, pola mengorganisasikan pembuktian yang logik.

2. Matematika itu adalah bahasa, bahasa yang menggunakan istilah yang didefinisikan dengan cermat, jelas, akurat dengan simbol yang padat, lebih berupa bahasa simbul mengenai arti daripada bunyi.

3. Matematika adalah pengetahuan struktur yang terorganisasi, sifat-sifat atau teori-teori dibuat secara deduktif berdasarkan kepada unsur yang tidak didefinisikan, aksioma, sifat atau teori yang telah dibuktikan kebenarannya.

4. Matematika adalah ilmu tentang pola keteraturan pola atau ide.

Matematika adalah suatu seni, keindahannya terdapat pada keteraturan dan keharmonisan [6]. Reys menyatakan bahwa matematika diartikan sebagai telaahan tentang pola dan hubungan, suatu jalan atau pola berpikir, suatu seni, suatu bahasa dan suatu alat [6]. Romberg mengarahkan hasil penelaahannya tentang matematika kepada tiga sasaran utama, yaitu:Para sosiolog, psikolog, pelaksana administrasi sekolah, dan penyusun kurikulum memandang bahwa matematika merupakan ilmu yang statis dan disiplin ketat. Selama kurun waktu dua dekade terakhir ini, matematika dipandang sebagai suatu usaha atau kajian ulang terhadap matematika itu sendiri. Matematika juga dipandang sebagai suatu bahasa, struktur logika, batang tubuh dari bilangan dan ruang, rangkaian metode untuk menarik kesimpulan, esensi ilmu terhadap dunia fisik, dan sebagai aktivitas intelektual [6].

Bourne memahami matematika sebagai kontruktivisme sosial dengan penekanannya pada knowing how, yaitu pelajar dipandang sebagai makhluk yang aktif dalam mengonstruksi ilmu pengetahuan dengan cara berinteraksi dengan lingkungannya [2]. Hal ini berbeda dengan pengertian knowing that yang dianut oleh kaum absolutis, di mana pelajar dipandang sebagai makhluk yang pasif dan seenaknya dapat diisi informasi dari tindakan hingga tujuan.

Sejalan dengan pandangan diatas Sujono mengemukakan beberapa pengertian matematika. Diantaranya, matematika diartikan sebagai cabang ilmu pengetahuan yang eksak dan terorganisasi secara sistematik. Selain itu, matematika merupakan ilmu pengetahuan tentang penalaran yang logik dan masalah yang berhubungan dengan bilangan. Bahkan Sujono mengartikan matematika sebagai ilmu bantu menginterpretasikan berbagai ide dan kesimpulan [2].

James dan James mengatakan bahwa matematika adalah ilmu tentang logika mengenai bentuk, susunan, besaran, dan konsep-konsep berhubungan lainnya dengan jumlah yang banyak yang terbagi ke dalam tiga bidang, yaitu aljabar, analisis dan geometri [13]. Kemudian Kline mengatakan pula bahwa matematika itu bukanlah pengetahuan menyendiri yang dapat sempurna karena dirinya sendiri, tetapi adanya matematika itu terutama untuk membantu mausia dalam memahami dan menguasai permasalahan sosial, ekonomi, dan alam [13].

Berdasarkan uraian di atas, dapat disimpulkan bahwa matematika adalah ilmu pengetahuan yang eksak dan terorganisasi secara sistematik, tentang penalaran yang logik dan masalah yang berhubungan dengan bilangan, ruang dan waktu, menginterpretasikan berbagai ide dan kesimpulan, suatu ilmu seni kreatif, suatu jalan atau pola berpikir, suatu bahasa simbol dan suatu alat, serta ilmu pengetahuan yang memahami dan menguasai permasalahan sosial, ekonomi, dan alam.

\section{Alat Peraga dan Manfaatnya}

Alat peraga berfungsi untuk menerangkan atau memperagakan suatu mata pelajaran dalam proses belajar mengajar. Dalam kegiatan belajar mengajar guru harus mampu menjelaskan konsep kepada siswanya. Usaha ini dapat dibantu dengan alat peraga matematika, karena dengan bantuan alatalat tersebut, yang sesuai dengan topik yang diajarkan, konsep akan dapat lebih mudah dipahami lebih jelas.

Salah satu peranan alat peraga dalam matematika adalah meletakkan ide-ide dasar konsep. Dengan bantuan alat peraga yang sesuai, siswa dapat memahami ide-ide dasar yang melandasi sebuah konsep, mengetahui cara membuktikan suatu 
rumus atau teorema, dan dapat menarik suatu kesimpulan dari hasil pengamatannya.

Setelah siswa mendapat kesempatan terlibat dalam proses pengamatan dengan bantuan alat peraga, maka dapat diharapkan akan tumbuh minat belajar matematika pada dirinya, dan akan menyenangi konsep yang disajikan, karena sesuai dengan tahap perkembangan mentalnya, yang masih menyenangi permainan.

Selain tumbuhnya minat, siswa juga dapat dibangkitkan motivasinya. Melalui demonstrasi penggunaan alat peraga matematika, guru dapat merangsang munculnya motivasi dalam diri siswa untuk mempelajari materi lebih lanjut. Siswa yang merasa penasaran dan ingin tahu lebih jauh tentang konsep yang dipelajarinya akan terus berusaha mempelajari konsep itu lebih mendalam.

Selain itu, pengajaran dengan menggunakan alat peraga akan dapat memperbesar perhatian siswa terhadap pengajaran yang dilangsungkan, karena mereka terlibat dengan aktif dalam pengajaran yang dilaksanakan. Dengan bantuan alat peraga konsentrasi belajar dapat lebih ditingkatkan.Alat peraga dapat pula membantu siswa untuk berpikir logis dan sistematis, sehingga mereka pada akhirnya memiliki pola pikir yang diperlukan dalam mempelajari matematika.

Dengan bantuan alat peraga matematika, siswa akan semakin mudah memahami hubungan antara matematika dan lingkungan alam sekitar. Siswa akan semakin mudah memahami kegunaan matematika dalam kehidupan sehari-hari. Diharapkan, dengan adanya kesadaran seperti ini, mereka terdorong untuk mempelajari matematika lebih lanjut. Misalnya dengan penggunaan alat peraga dalam penjelasan konsep ruang berdimensi tiga, siswa akan semakin terlatih daya tarik ruangnya, sehingga pada akhirnya mampu menemukan atau menyadari hubungan antara matematika dengan lingkungan sekitar[11].

Menurut beberapa hasil penelitian, penggunaan alat peraga menunjang penjelasan konsep matematika. Penelitian yang dilaksanakan oleh Higgins dan Suydam, memberikan hasil-hasil diantaranya bahwa alat peraga berfungsi efektif dalam memotivasi belajar siswa; memanipulasi alat peraga sangat penting bagi siswa; terdapat sedikit bukti yang menggambarkan bahwa memanipulasi alat peraga hanya berhasil bagi siswa-siswa yang tingkat rendah; gambar dari benda; sebagai alat peraga dalam pengajaran; memiliki kegunaan yang tidak jauh berbeda dengan bendanya sendiri [13].

Penggunaan alat peraga harus dilaksanakan secara cermat. Jangan sampai konsep menjadi lebih rumit akibat diuraikan dengan bantuan alat peraga. Alat peraga harus digunakan secara tepat, disesuaikan dengan sifat materi yang disampaikan, metode pengajaran yang digunakan dan tahap perkembangan mental anak.

Penggunaan alat peraga harus mampu menghasilkan generalisasi atau kesimpulan abstrak dari representasi konkret. Maksudnya, dengan bantuan alat peraga yang sifatya konkret, siswa diharapkan mampu menarik kesimpulan.

Alat peraga yang digunakan tanpa persiapan bisa mengakibatkan habisnya waktu dan sedikitnya materi yang dapat disampaikan. Jika ini yang terjadi, maka dapat dikatakan bahwa alat peraga yang kita pakai atau cara penggunaan alat peraga yang kita lakukan tidak mancapai sasaran. Konsep yang menjadi semakin rumit untuk dipahami sebagai akibat digunakannya alat peraga, adalah suatu hal yang keliru. Jika suatu topik tertentu tidak memerlukan penggunaan alat peraga, penggunaan alat peraga tidak harus dipaksakan, sebab alat peraga pada hakikatnya tidak harus digunakan untuk setiap penjelasan topik-topik dalam matematika.

Alat peraga harus dibuat sebaik mungkin, menarik untuk diamati, dan mendorong siswa untuk bersifat penasaran, sehingga diharapkan motivasi belajarnya semakin meningkat.Alat peraga juga diharapkan menumbuhkan daya imajinasi dalam meningkatkan daya tarik ruangnya, mampu membandingkannya dengan benda-benda sekitar dalam lingkungannya sehari-hari, dan mampu menganalisis sifat-sifat benda yang dihadapinya itu.

Misalnya, jika siswa telah menggunakan sebuah kubus, untuk mempelajari sifat-sifat yang dimiliki kubus, siswa terdorong untuk meneliti sifat-sifat benda nyata di alam sekitar yang memiliki bentuk serupa dengan kubus.

Dari uraian diatas dapat disarikan bahwa beberapa manfaat penggunaan alat peraga diantaranya adalah membantu guru dalam memberikan penjelasan konsep, merumuskan atau membentuk konsep, melatih siswa dalam keterampilan, memberi penguatan konsep pada siswa, melatih 
siswa dalam pemecahan masalah, mendorong siswa dalam berpikir kritis dan analitik dan mendorong siswa untuk melakukan pengamatan terhadap suatu objek secara sendiri.

\section{Hasil Belajar dan Pengaruhnya}

Hasil belajar adalah kemampuan yang diperoleh anak setelah melalui kegiatan belajar. Belajar itu sendiri merupakan suatu proses dari seseorang yang berusaha untuk memperoleh suatu bentuk perubahan perilaku yang relatif menetap[5]. Dalam kegiatan pembelajaran atau suatu intruksional, biasanya guru menetapkan tujuan belajar. Siswa yang berhasil dalam belajar adalah yang berhasil mencapai tujuan-tujuan pembelajaran atau tujuan intruksional.

Juliah mengatakan bahwa hasil belajar adalah segala sesuatu yang menjadi milik siswa sebagai akibat dari kegiatan belajar yang dilakukannya[13]. Menurut Sudjana dan Ibrahim yang dikutip oleh Jihad dan Haris hasil belajar adalah setiap proses belajar mengajar keberhasilannya diukur dari seberapa jauh hasil belajar yang dicapai siswa, disamping diukur dari segi prosesnya, artinya seberapa jauh tipe hasil belajar dimiliki siswa. Sedangkan Sudrajad mengatakan bahwa hasil belajar adalah adalah penilaian untuk memperoleh informasi sejauh mana proses penilaian peserta didik atau ketercapaian kompetansi peserta didik [1].

Hasil belajar yang dicapai oleh siswa sangat erat kaitannya dengan rumusan tujuan instruksional yang direncanakan guru sebelumnya yang dikelompokkan kedalam tiga kategori, yakni domain kognitif, afektif, dan psikomotor. Perubahan salah satu atau ketiga domain yang disebabkan oleh proses belajar yang dinamakan hasil belajar. Hasil belajar dapat dilihat dari ada tidaknya perubahan ketiga domain tersebut yang dialami siswa setelah menjalani proses belajar.

Tujuan hasil belajar adalah untuk mengetahui sampai dimana pencapaiaan peserta didik terhadap bahan pengajaran setelah mengalami suatu kegiatan belajar[10]. Kemajuan hasil belajar siswa tidak saja diukur dari tingkat penguasaan ilmu pengetahuan tetapi juga sikap dan keterampilan. Dengan demikian penilaian hasil belajar siswa mencangkup segala hal yang dipelajari di sekolah, baik itu menyangkut pengetahuan sikap dan keterampilan.
Hasil belajar dapat dilakukan melalui evaluasi yang diberikan guru kepada peserta didik berdasarkan apa yang telah diperolehnya dari belajar. Penilaian hasil belajar merupakan "gambaran kemampuan menyeluruh atau umum secara konstektual mengenai kemampuan siswa dalam menerapkan konsep dan pemahaman mata pelajaran". Untuk mengukur hasil belajar, penilaian dapat ditujukan kepada proses pembelajaran, yaitu untuk mengetahui sejauh mana tingkat keterlibatkan siswa dalam proses pembelajaran. Semakin baik proses pembelajaran dan keaktifan siswa dalam mengikuti proses pembelajaran, maka semakin tinggi hasil belajar yang diperoleh siswa.

Berdasarkan uraian di atas, dapat disimpulkan bahwa hasil belajar adalah kemampuan yang diperoleh anak setelah melalui kegiatan belajar dalam pencapaian bentuk perubahan perilaku yang cenderung menetap dari ranah kognitif, afektif, dan psikomotorik dari proses belajar yang dilakukan dalam waktu tertentu yang sangat erat kaitannya dengan rumusan tujuan instruksional yang direncanakan guru sesuai dengan tujuan pengajaran.

Untuk memahami kegiatan yang disebut belajar, perlu dilakukan analisis untuk menemukan persoalan-persoalan apa yang terlibat di dalam kegiatan belajar itu. Belajar merupakan suatu proses. Sebagai suatu proses sudah tentu harus ada yang diproses dan hasil dari pemproses. Jadi dalam hal ini kita dapat menganalisis kegiatan belajar itu dengan pendekatan analisis sistem [12]. Dengan pendekatan analisis sistem ini sekaligus kita dapat melihat adanya berbagai faktor yang dapat mempengaruhi proses dan hasil belajar.

Beberapa faktor internal yang mempengaruhi proses belajar siswa, yaitu karakteristik siswa, sikap terhadap belajar, motivasi belajar, konsentreasi belajar, mengelola bahan ajar, menggali hasil belajar, rasa percaya diri, dan kebiasaan belajar. Keberhasilan belajar siswa di samping ditentukan oleh faktor-faktor internal juga dipengaruhi oleh faktor-faktor eksternal. Faktor eksternal adalah segala yang ada di luar diri siswa yang memberikan pengaruh terhadap aktivitas dan hasil belajar yang dicapai siswa. Faktor-faktor yang mempengaruhi hasil belajar siswa antara lain adalah faktor guru, lingkungan sosial, kurikulum sekolah, sarana dan prasarana. 
Abdillah mengemukakan bahwa sebagai pembimbing dalam proses belajar mengajar, seorang guru diharapkan mampu memberikan informasi yang diperlukan dalam proses belajar, membantu setiap siswa dalam mengatasi setiap masalah pribadi yang dihadapinya, mengevaluasi hasil setiap langkah kegiatan yang telah dilakukannya, memberikan setiap kesempatan yang memadai agar setiap murid dapat belajar sesuai dengan karakteristik pribadinya, mengenal dan memahami setiap murid baik secara individual maupun secara kelompok.

Karena keberhasilan belajar merupakan muara dari seluruh aktivitas yang dilakukan guru dan siswa dalam proses pembelajaran. Maka setiap guru harus berupaya secara optimal memahami berbagai faktor yang dapat menyebabkan terjadinya hambatan-hambatan dalam proses dan hasil belajar.

\section{METODOLOGI PENELITIAN}

\section{Tempat dan Waktu Penelitian}

Penelitian ini dilakukan di SD Islam Al Azhar di Jakarta. Waktu pelaksanaan penelitian berlangsung selama 7 ( tujuh ) bulan.

3.2 Metode Penelitian

Berdasarkan rumusan masalah dan kerangka berfikir serta pengajuan hipotesis seperti yang termuat pada bab 2 , metode penelitian digunakan dalam penelitian untuk untuk mencapai tujuan yang diinginkan. Penulis menggunakan jenis penelitian deskriptif kuantitatif.

\section{Populasi dan Sampel}

Populasi target dalam penelitian ini adalah seluruh siswa kelas mekah dan kelas madinah SD Islam Al Azhar Pusat di Yayasan Pesantren Islam Al Azhar di Jakarta berjumlah 98 orang, sedangkan Populasi terjangkau dalam penelitian ini berjumlah 50 orang dengan teknik pengambilan sampel menggunakan cara sampling acak sederhana.

\section{Teknik Analisis Data}

\section{Analisis Deskriptif dan Inferensial}

Dalam analisis deskriptif akan dilakukan teknik penyajian data dalam bentuk tabel distribusi frekuensi. Selain itu juga masing-masing kelompok data akan diolah dan dianalisis ukuran pemusatan dan letak seperti mean, modus, dan median serta ukuran simpangan seperti jangkauan, variansi, simpangan baku, kemencengan dan kurtosis. Proses pengolahan untuk menguji analisis deskriptif tersebut dilakukan dengan menggunakan program SPSS 22.0.

Data yang diperoleh dari hasil penelitian dianalisis dengan menggunakan analisis statistik deskriptif dan analisis statistik ANAVA dan Uji t. Analisis statistik deskriptif dilakukan dengan mendeskripsikan semua data dari semua variabel dalam bentuk; distribusi frekuensi, histogram, modus, median, harga rata-rata serta simpangan baku (standar deviasi). Sedangkan analisis statistic ANAVA dilakukan untuk menguji pengaruh hipotesis yang telah dirumuskan. Sebelumnya terlebih dahulu dilakukan pengujian persyaratan analisis yaitu uji normalitas dan uji homogenitas.

\section{Uji Persyaratan Analisis Data}

Uji persyaratan analisis data dimaksudkan untuk mengetahui apakah data yang telah dikumpulkan layak untuk dianalisis lebih lanjut menggunakan alat-alat statistik. Pengujian yang dilakukan adalah pengujian normalitas data, pengujian linieritas yang secara keseluruhan dibantu oleh program komputer SPSS 22.0. Adapun kriteria pengujian untuk normalitas adalah: jika nilai sig > 0,05; maka data berdistribusi normal dan jika nilai sig < 0,05; maka data tidak beridistribusi normal.

Sementara itu kriteria pengujian linieritas adalah jika $F_{\text {hitung }}>F_{\text {tabel }}$ atau nilai sig $<0,05$; maka persamaan regresi linier. Jika $F_{\text {hitung }}<\mathrm{F}_{\text {tabel }}$ atau nilai sig $>0,05$; maka persamaan regresinya tidak linier.

\section{Uji Hipotesis Penelitian}

Setelah keseluruhan uji persyaratan analisis data dipenuhi dan diketahui data layak untuk diolah lebih lanjut, maka langkah berikutnya adalah menguji masing-masing hipotesis yang telah diajukan. Pengujian hipotesis menggunakan ANAVA. Data yang diperoleh diolah dengan menggunakan SPSS 22.0.

Pengujian statistik menggunakan hipotesis nol dan hipotesis alternatif sebagai berikut:

$\mathrm{H}_{0}: \rho_{1}=0 \rightarrow$ tidak ada pengaruh penggunaan alat peraga terhadap hasil pembelajaran matematika pada anak usia dini.

$\mathrm{H}_{1}: \rho_{1} \neq 0 \rightarrow$ ada pengaruh penggunaan alat peraga terhadap hasil pembelajaran matematika pada anak usia dini. 


\section{HASIL PENELITIAN DAN PEMBAHASAN}

\section{Deskripsi Data Penelitian}

Untuk menguji hipotesis penelitian maka dilakukan beberapa tahapan analisis, meliputi tahap analisis statistik deskriptif dengan mendeskripsikan data masing-masing variabel. Selanjutnya dilakukan uji persyaratan analisis data yaitu uji normalitas dan homogenitas data. Jika data dinyatakan layak maka dilanjutkan dengan pengujian hipotesis penelitian menggunakan ANAVA. Berikut disajikan rangkuman data deskripsi hasil penelitian:

Tabel 4.1.Rangkuman Data Deskriptif

\begin{tabular}{lrr}
\hline Statistik & Kontrol & \multicolumn{1}{c}{ Alat Peraga } \\
\hline Rata-rata & 45.30 & 84.10 \\
Median & 55.00 & 84.50 \\
Modus & 22 & 85 \\
Standar deviasi & 17.856 & 5.785 \\
Nilai terendah & 22 & 75 \\
Nilai tertinggi & 70 & 95 \\
\hline
\end{tabular}

\section{Pengujian Persyaratan Analisis}

\section{Uji Normalitas}

Uji normalitas data dimaksudkan untuk memperlihatkan bahwa data sampel berasal dari populasi yang berdistribusi normal. Uji normalitas data yang dilakukan adalah dengan menggunakan teknik uji kolmogorov-smirnov pada taraf signifikansi $\alpha=0,05$ dengan bantuan program SPSS 22. Hasil perhitungannya disajikan pada tabel berikut:

Tabel 4.2.Perhitungan Normalitas Data Sampel

\begin{tabular}{|c|c|}
\hline Statistika & $\begin{array}{l}\text { Hasil Belajar } \\
\text { Matematika }\end{array}$ \\
\hline Nilai kolmogorov-smirnov & 0.134 \\
\hline Signifikansi & 0.009 \\
\hline
\end{tabular}

Dari tabel 4.2 diperoleh nilai Sig. (2-tailed) $=$ 0,143 . Karena nilai Sig. (2-tailed) $>\alpha=0,05$, maka data sampel berasal dari populasi yang berdistribusi normal. Dengan demikian dapat disimpulkan bahwa sampel penelitian ini berasal dari populasi yang berdistribusi normal. Kesimpulan ini memberikan implikasi bahwa analisis statistika selanjutnya dapat digunakan dalam penelitian ini.

\section{Uji Homogenitas}

Pengujian homogenitas pada sampel dilakukan dengan Uji Bartlet pada taraf signifikansi $\alpha=5 \%$. Adapun ringkasan hasil perhitungan uji homogenitas masing-masing kelompok sampel diberikan pada tabel berikut:

Tabel 4.3 Hasil Uji Homogenitas

\begin{tabular}{cc}
\hline Levene Statistic & Sig. \\
\hline 0.207 & 0.891
\end{tabular}

Hasil perhitungan uji homogenitas menunjukkan bahwa Lavene test hitung adalah 0,207 dengan nilai probabilitas sig $=0,891$. Karena nilai probabilitas sig >0,05, maka sampel berasal dari populasi yang memiliki varians homogen.

\section{Pengujian Hipotesis Penelitian}

Sesudah memenuhi asumsui-asumsi bahwa data berada dalam sebaran normal dan varians yang homogen maka dapat dilanjutkan dengan pengujian hipotesis penelitian. Hipotesis penelitian menggunakan analisis varians (ANAVA). Dalam pengujian hipotesis ini digunakan program SPSS 22. Berikut adalah hasil ringkasan analisis data tersebut.

Tabel 4.3 Rangkuman Hasil ANAVA Data Hasil Belajar Matematika Siswa

\begin{tabular}{lcrcrc}
\hline & $\begin{array}{c}\text { Sum of } \\
\text { Squares }\end{array}$ & Df & Mean & & \\
& Square & F & Sig. \\
\hline Between & 15428.933 & 2 & 7714.46 & 62.44 & .000 \\
Groups & & & 7 & 3 & \\
Within & 7042.000 & 57 & 123.544 & & \\
Groups & & & & & \\
Total & 22470.933 & 59 & & & \\
\hline
\end{tabular}

Berdasarkan hasil perhitungan pada tabel 4.3 dapat disimpulkan :Hipotesis ini untuk menguji ada atau tidaknya pengaruh penggunaan alar peraga terhadap hasil belajar matematika. Dengan kata lain mengetahui seberapa besar penggunaan alat peraga mempengaruhi hasil belajar matematika dengan hipotesis statistik sebagai berikut :

$\mathrm{H}_{0}$ : Tidak ada pengaruh penggunaan alat peraga terhadap hasil belajar matematika

$\mathrm{H}_{1}$ : Terdapat pengaruh penggunaan alat peraga terhadap hasil belajar matematika

Hipotesis diuji dengan melihat koefisien signifikan.

Jika nilai sig > 0,05; maka $\mathrm{H}_{0}$ diterima dan $\mathrm{H}_{1}$ ditolak 
Jika nilai sig $<0,05$; maka $\mathrm{H}_{1}$ diterima dan $\mathrm{H}_{0}$ ditolak

\section{Pembahasan Hasil Penelitian}

Berdasarkan hasil anava satu jalan dengan menggunakan SPSS 22 diperoleh nilai sig $(0,000<$ $0,05)$ untuk penggunaan alat peraga, dengan demikian dapat disimpulkan terdapat pengaruh penggunaan alat peraga terhadap hasil belajar matematika. Hal ini didukung oleh perolehan rerata skor hasil belajar matematika dengan penggunaan alat peraga lebih tinggi dari hasil belajar matematika tanpa penggunaan alat peraga yaitu 84,1. Hal ini menunjukkan bahwa hasil belajar matematika akan meningkat bila siswa diajar dengan penggunaan alat peraga. Penelitian ini sejalan dengan temuan Mariani yang menyatakan bahwa pembelajaran yang menggunakan alat peraga dapat meningkatkan hasil belajar Matematika pada siswa. Pendekatan konstruktivistik melalui alat peraga menekankan kepada pembentukan pengetahuan siswa. Selama proses pembelajaran dibiasakan adanya suatu konstruksi kognitif kenyataan melalui kegiatan seseorang, bukan merupakan suatu barang yang ditransfer begitu saja dari pikiran yang mempunyai pengetahuan ke pikiran orang yang belum mempunyai pengetahuan [8].

Komalasari juga menyatakan bahwa alat peraga adalah alat (benda) yang digunakan untuk memperagakan fakta, konsep, prinsip atau prosedur tertentu agar tampak lebih nyata/konkret. Pada dasarnya siswa belajar melalui sesuatu yang konkret [7]. Untuk memahami konsep abstrak anak memerlukan benda-benda konkret sebagai perantara atau visualisasinya. Dalam pembelajaran dengan pendekatan konstruktivistik berbantuan alat peraga, siswa terbiasa membawa konsepsi awal mereka yang diperoleh selama berinteraksi dengan lingkungan dalam kegiatan belajar mengajar. Lebih lanjut, guru berusaha mencari pandangan atau pendapat siswa dan membuatnya sebagai titik tolak untuk memulai pembelajaran, proses pembelajaran diarahkan untuk menantang apa yang menjadi keyakinan siswa, siswa juga diberi kesempatan untuk dapat menemukan (membentuk) relasi matematis sendiri, jangan selalu dihadapkan pada pemikiran orang dewasa yang sudah jadi, dan dalam sajian proses pembelajarannya sering memunculkan masalahmasalah yang relevan dengan siswa. Akibatnya kelebihan-kelebihan tersebut memberikan dampak positif terhadap hasil belajar siswa. Pendekatan konstruktivistik berbantuan alat peraga konkret memberi kebebasan kepada siswa untuk membangun pengetahuan dengan menggunakan beragam sumber belajar yang tersedia menggunakan bantuan alat yang dapat memeragakan konsep secara nyata/konkret sehingga dapat mempermudah pemahaman siswa dalam pembelajaran

\section{PENUTUP}

\section{Kesimpulan}

Berdasarkan hasil pengumpulan, pengolahan dan analisa data penelitian maka dapat disimpulkan bahwa terdapat pengaruh penggunaan alat peraga terhadap hasil belajar matematika.

\section{Saran - Saran}

Berdasarkan kesimpulan dari hasil pengumpulan, pengolahan dan analisa data maka peneliti menyarankan sebagai berikut :

1. Penelitian ini masih memerlukan penelitian lebih lanjut tentang pengaruh beberapa jenis alat peraga terhadap hasil pembelajaran.

2. Bagi guru yang ingin meningkatkan prestasi belajar matematika siswa-siswinya hendaknya dalam pengajaran matematika memggunakan alat peraga.

3. Demi tercapainya tujuan pembelajaran matematika maka pihak sekolah diharapkan agar dapat mengadakan sarana dan prasarana yang dapat menunjang kegiatan pembelajaran termasuk alat peraga pembelajaran.

\section{DAFTAR PUSTAKA}

[1] Aunurrahman. 2009. Belajar dan Pembelajaran. Bandung: Alfabeta.

[2] Fathani dan Abdul Hakim. 2009. Matematika Hakikat dan Logika. Jogyakarta: Ar- Ruzz Media.

[3] Harjanto. 2003. Perencanaan Pegajaran. Jakarta: PT Rineka Cipta.

[4] Jamaris, Martini. 2006. Perkembangan dan Pengembangan Anak Usia Taman Kanak-Kanak. Jakarta: Grasindo.

[5] Jihad, Asep. 2008. Pengembangan Kurikulum Matematika. Yogyakarta: Multi Pressindo.

[6] Jihad, Asep dan Abdul Haris. 2008. Evaluasi Pembelajaran. Yogyakarta: Multi Pressindo.

[7] Komalasari. 2010. Pembelajaran Kontekstual Konsep Aplikasi. Bandung: Refika Aditama.

[8] Mariani. 2009. Pengaruh Pembelajaran Kontekstual dan Motivasi Berprestasi Terhadap Hasil Pembelajaran IPA pada Siswa Kelas V di SDN 1 dan 3 Renon Denpasar Selatan. Undiksha. 
[9] Sadiman, Arif Sukardi. 1988. Beberapa Aspek Pengembangan Sumber Belajar. Jakarta: Mediayatama Sarana Perkasa.

[10] Sudono, Snggani. 2000. Sumber Belajar dan Alat Permainan. Jakarta; Mediyatama Sarana Perkasa.

[11] Sjiono, Bambang dan Yuliani Nurani Sujiono. 2005. Menu Pembelajaran Anak Usia Dini. Jakarta: Yayasan Citra Pendidikan Indonesia.
[12] Syah, Muhibbin. 2008. Psikologi Pendidikan dengan Pendekatan Baru. Bandung: Remaja Rosdakarya.

[13] Udin S. Winataputra, dkk. 1992. Materi Pokok Strategi Belajar Mengajar Matematika; 1-9. Jakarta: Universitas Terbuka, Departemen Pendidikan dan Kebudayaan. 